Gut, 1984, 25, 953-956

\title{
Pentagastrin induced motility pattern in the human upper gastrointestinal tract is reversed by proglumide
}

\author{
J F ERCKENBRECHT, J CASPARI, AND M WIENBECK \\ From the Department of Internal Medicine D, University of Düsseldorf, Düsseldorf, FR Germany
}

SUMMARY The effects of pentagastrin and the putative gastrin antagonist proglumide on interdigestive motility of the upper small bowel were studied in a randomised double blind study in 10 healthy human volunteers. Intraluminal pressures were recorded manometrically in the duodenum and jejunum for five hours. Sixty minutes after starting a pentagastrin infusion $(0.15 \mu \mathrm{g} / \mathrm{kg} / \mathrm{h})$ either placebo or proglumide was infused intravenously. Pentagastrin converted the normal interdigestive motility to irregular motor activity, while proglumide restored the periodic fasted pattern. We conclude that gastrin is a likely candidate involved in the conversion of the fasted to the fed motility pattern in the human upper gut.

In the fasted state, motility of the stomach and small intestine of man is characterised by periodic activity of the interdigestive migrating motor complex (MMC). ${ }^{1-4}$ Immediately after feeding, gastrointestinal motility becomes irregular. ${ }^{4}$ In the conversion of the interdigestive to the digestive motility pattern not only neural mechanisms, ${ }^{5}$ but also gastrointestinal hormones, particularly cholecystokinin (CCK) and gastrin, appear to be involved. ${ }^{6-8}$ This is illustrated by recent observations, showing that endogenous gastrin interrupts the migrating motor complex in an autotransplanted, denervated fundic pouch. ${ }^{9}$

Proglumide inhibits the CCK stimulated secretion of dispersed pancreas acini,${ }^{10}$ and also the motor response of isolated smooth muscle cells after stimulation by CCK octapeptide. ${ }^{11}$ These and other findings ${ }^{12} 13$ support the concept of proglumide being an antagonist of CCK and gastrin at the receptor site.

The present study examines the effect of pentagastrin infused at a dose that produces a rise in gastric acid secretion similar to the increased serum gastrin seen after feeding, ${ }^{14}$ and its combination with the putative gastrin antagonist proglumide on the interdigestive motility of the human upper gastrointestinal tract.

Address for correspondence: Dr J F Erckenbrecht. Dept of Internal Medicine D. University of Düsseldorf. Moorenstrasse 5, D-4000 Düsseldorf 1, FR Germany.

Received for publication 18 November 1983

\section{Methods}

SUBJECTS

Ten healthy male volunteers (mean age $25 \pm 2$ $(\bar{x} \pm S D)$ years) were examined in a double blind, randomised, crossover study after giving informed consent.

Intraluminal pressures were measured manometrically by a triple lumen polyvinyl tube. The inside diameter of the three catheters was $0.8 \mathrm{~mm}$ each. The distal side openings of the three catheters were $20 \mathrm{~cm}$ apart. Beyond the side openings the catheters were occluded by a stainless steel plug. At their proximal ends the catheters were connected to pressure transducers. Pressure events were recorded via a bridge amplifier (Hellige TF 19) on a direct writing polygraph (Hellige P 31). The pressure transducers and the catheters were continuously perfused by a low compliance pneumohydraulic pump $^{15}$ at a rate of $9 \mathrm{ml} \mathrm{H} \mathrm{O} \mathrm{h}^{-1}$.

Before each experiment the volunteers were fasted for 10 hours. The manometric tube was introduced through the mouth and positioned under radiographic control with its side openings into the duodenum and jejunum. The initial basal registration was continued, until the first activity front of the MMC had passed the duodenum. Then the volunteers received pentagastrin $0.15 \mu \mathrm{g} / \mathrm{kg}$ bodyweight/ $h$ by intravenous infusion for five hours. Sixty minutes after starting the pentagastrin infusion, in addition, either proglumide or the same volume of placebo solution (normal saline) was 
infused for four hours in a double blind fashion. The dose of proglumide was $400 \mathrm{mg}$ as an initial $5 \mathrm{ml}$ bolus followed by an infusion of $500 \mathrm{mg} / \mathrm{h}$.

The order of the experiments (pentagastrin + proglumide or pentagastrin + placebo) was randomised. After the start of the additional infusion (proglumide or placebo), the pressure recordings were continued for four hours. The control experiment with either placebo or proglumide followed within one week. Serum proglumide concentrations were determined by gas chromatography. ${ }^{16}$

We evaluated the number of activity fronts of the MMC in the duodenum and jejunum. Differences between the proglumide and placebo experiments were tested for significance by Student's $t$ test for paired data.

\section{Results}

The results are given in Figures 1 and 2. Pentagastrin $0 \cdot 15 \mu \mathrm{g} / \mathrm{kg}$ bodyweight $/ \mathrm{h}$ interrupted the normal interdigestive motility pattern of the upper intestine (Fig. 1). During pentagastrin infusion the number of activity fronts in the duodenum and jejunum was reduced to $0 \cdot 4 \pm 0 \cdot 2(\overline{\mathrm{x}} \pm \mathrm{SEM} / 4 \mathrm{~h})$. Irregular contractions prevailed (Fig. 3 ).

Infusion of proglumide in addition to pentagastrin restored the normal periodic interdigestive motor activity (Fig. 2). The mean period of the MMC was approximately two hours. The number of activity fronts of the MMC increased to $2 \cdot 0 \pm 0.5 / 4 \mathrm{~h}$ $(\bar{x} \pm \mathrm{SEM} / 4 \mathrm{~h})$ in the duodenum $(\mathrm{p}<0 \cdot() 2$ compared with pentagastrin + placebo), and to $1 \cdot 7 \pm 0 \cdot 4 / 4 \mathrm{~h}$ in the jejunum $(p<0 \cdot 01)$.

Serum proglumide concentrations were determined 30 minutes and 240 minutes after the start of the proglumide infusion. After 30 minutes proglumide infusion serum concentrations ranged from $0.58 \mu \mathrm{g} / \mathrm{ml}$ to 28.26 (median 3.8 ), they were less than $2 \mu \mathrm{g} / \mathrm{ml}$ in seven subjects. Two hundred and forty minutes after the beginning of the proglumide infusion serum concentrations ranged from $0.58 \mu \mathrm{g} / \mathrm{ml}$ to $39.2 \mu \mathrm{g} / \mathrm{ml}$ (median 5.4 ), they were less than $2 \mu \mathrm{g} / \mathrm{ml}$ in seven subjects. There was no clear relationship between the serum proglumide concentrations 30 or 240 minutes after starting the proglumide infusion and the number of activity fronts of the MMC.

\section{Discussion}

In the interruption of cyclic interdigestive motility after feeding not only neural mechanisms, but also gastrointestinal hormones appear to be involved. Endogenous gastrin ${ }^{9}$ and exogenous administration of $\mathrm{CCK}^{8}$ have been found to convert the fasted to the fed motility pattern which is characterised by apparently irregular contractile activity.

The present study shows that the administration of pentagastrin in a dose which stimulates gastric acid secretion to a similar extent as the postprandial gastrin rise interrupts the regular periodic interdigestive motility in the upper gastrointestinal tract. Activity fronts of the MMC are absent or their number clearly reduced. The motility pattern
Fig. 1 Effect of pentagastrin $(0 \cdot 15 \mu \mathrm{g} / \mathrm{kg} / \mathrm{h})$ on interdigestive motility of the duodenum (D) and jejunum $(\mathrm{J})$ in 10 healthy volunteers.

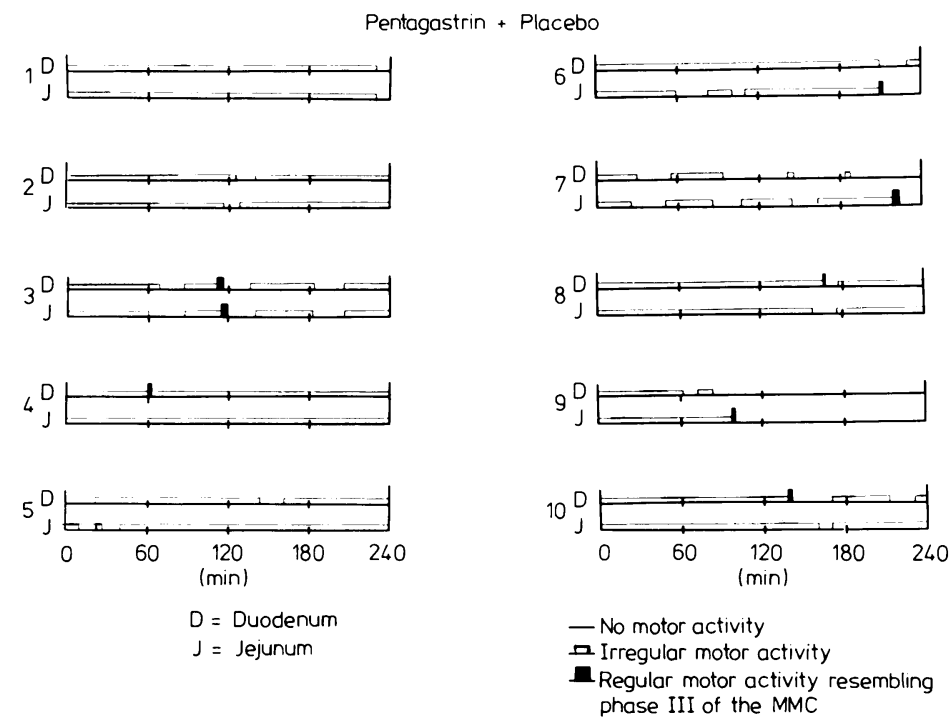




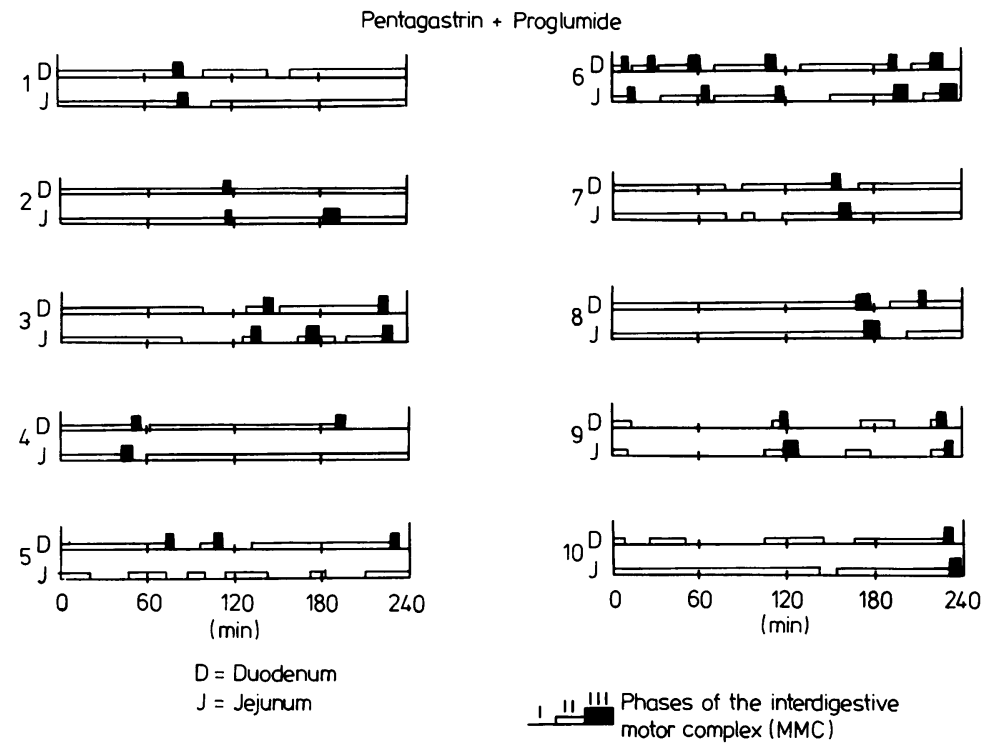

Fig. 2 Effect of pentagastrin $(0 \cdot 15 \mu \mathrm{g} / \mathrm{kg} / \mathrm{h})$ and proglumide ( $400 \mathrm{mg}$ as a bolus followed by $500 \mathrm{mg} / \mathrm{h}$ ) on interdigestive motility of the duodenum $(D)$, and jejunum $(\mathrm{J})$ in 10 healthy volunteers.

the hypothesis of proglumide being a gastrin- and CCK-receptor antagonist. ${ }^{10-13}$

Proglumide and pentagastrin have direct actions brought about by pentagastrin administration is characterised by irregular motor activity. These findings lend support to the idea that the serum gastrin rise after feeding is involved in the conversion of the interdigestive to the digestive motility pattern in the upper gut. ${ }^{679}$

Additional infusion of proglumide restores the interdigestive motility pattern which has a mean period between activity fronts of the MMC of approximately two hours. These findings support on the gastrointestinal smooth muscle cell ${ }^{11} 17$ in that they appear to act on CCK and gastrin receptors. In these observations pentagastrin and gastrin were shown to increase myoelectrical and motor activity of the stomach, while proglumide inhibited myoelectric and motor activity in the isolated stomach and ileum. ${ }^{18}$ It is unlikely that

Fig. 3 Interdigestive motility of the duodenum $(D)$ and jejunum $(J)$ before and during pentagastrin + placebo and pentagastrin + proglumide infusion.
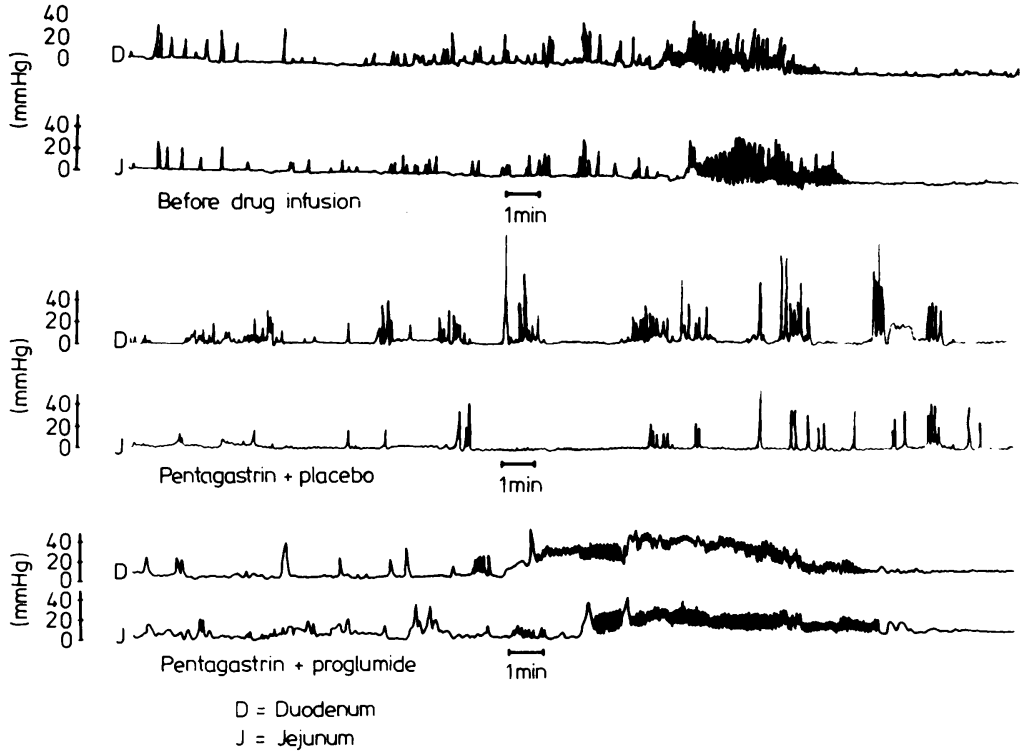
changes in gastric acid secretion play a major role in the motor effects of pentagastrin and proglumide, as (a) in animal experiments pentagastrin alters small intestinal motility even if gastric secretions are diverted from the duodenum ${ }^{7}$ and (b) proglumide has only weak actions on gastric acid secretion. ${ }^{19}$

Preliminary results of this study were presented to the American Gastroenterological Association, Chicago, May 1982 (Gastroenterology 1982; 82: 1050). We are indebted to Dr von Bergmann, University Hospitals, Bonn, FR Germany, for his measurements of serum proglumide.

\section{References}

1 Code CF, Schlegel JF. The gastrointestinal interdigestive housekeeper: motor correlates of the interdigestive myoelectric complex of the dog. In: Daniel $\mathrm{EE}$, ed. Proceedings of the 4th International Symposium on GI motility, Vancouver: Mitchell Press, 1973: 631-4.

2 Szurszewski JH. A migrating electric complex of the canine small intestine. Am J Physiol 1969; 217: 1757-63.

3 Vantrappen G, Janssens J, Hellemans J, Ghoos Y. The interdigestive motor complex of normal subjects and patients with bacterial overgrowth of the small intestine. J Clin Invest 1977; 59: 1158-66.

4 Wingate DL. Backwards and forwards with the migrating complex. Dig Dis Sci 1981; 26: 641-66.

5 Sarr MG, Kelly KA. Myoelectric activity of the autotransplanted canine jejunoileum. Gastroenterology 1981; 81: 303-10.

6 Marik F, Code CF. Control of the interdigestive myoelectric activity in dogs by the vagus nerves and pentagastrin. Gastroenterology 1975; 69: 387-95.

7 Weisbrodt NW, Copeland EM, Kearley RW, Moore EP, Johnson LR. Effects of pentagastrin on electric activity of small intestine of the dog. Am J Physiol 1974; 227: 425-9.

8 Schang J-C, Kelly KA. Inhibition of canine interdigestive proximal gastric motility by cholecystokinin octapeptide. Am J Physiol 1981; 240: G217-20.

9 Thomas PA, Schang J-C, Kelly KA, Go VLW. Can endogenous gastrin inhibit canine interdigestive gastric motility? Gastroenterology 1980, 78: 716-21.

10 Hahne WF, Jensen RT, Lemp GF, Gardner JD. Proglumide and benzotript: members of a different class of cholecystokinin receptor antagonists. Proc Natl Acad Sci USA 1981; 78: 6304-8.

11 Bitar KN, Makhlouf EM. Receptors on smooth muscle cells: characterization by contraction and specific antagonists. Am J Physiol 1982; 242: G400-7.

12 Cifarelli A, Setnikar I, Vidal y Plana PR. Antagonism of proglumide to human gastrin at sites on gastric cell membranes. In: Weiss J, Miederer SE, eds. Proglumide. Oxford: Excerpta Medica, 1980: 13-21.

13 Loewe CJ, Grider JR, Vlahcevic ZR. Effect of proglumide, a gastrin/CCK receptor antagonist, on gastric acid and pancreatic enzyme secretion in vivo. Gastroenterology 1983; 84: 1232.

14 Grossmann MI. What is physiological. Gastroenterology 1973; 65: 994.

15 Arndorfer RC, Stef JJ, Dodds WJ, Linehan JH, Hogan WJ. Improved infusion system for intraluminal esophageal manometry. Gastroenterology 1977; 73: 23-7.

16 Bignamini AA, Casula PL, Rovati AL. Pharmacokinetic approach to proglumide long-term activity. Arzneim Forsch 1979; 79: 639-42.

17 Morgan KG, Schmalz PF, Go VLW, Szurszewski JH. Effects of pentagastrin, $G 17$, and G 34 on the electrical and mechanical activities of canine antral smooth muscle. Gastroenterology 1978; 75: 405-12.

18 Benzi GM, Arrigoni E, Panceri P, Panzarasa R, Bertè F. Action of xylamide on gastrointestinal motor activity in animals and animal organs. Digestion 1973; 9: $149-65$.

19 Rovati AL. Inhibition of gastric secretion by antigastrinic and $\mathrm{H}_{2}$-blocking agents. Scand J Gastroenterol 1976; 11; suppl 42: 113-8. 